\title{
Evolutionary Biology at Belyaev Conference - 2017
}

\author{
Yuriy L. Orlov ${ }^{1,2^{*}}$, Ancha V. Baranova ${ }^{3,4}$ and Yuriy E. Herbeck \\ From Belyaev Conference \\ Novosibirsk, Russia. 07-10 August 2017
}

Current collection continues the series of BioMed Central special post-conference issues presenting the highlights from the set of conferences on bioinformatics and systems biology held in Novosibirsk and Moscow (Russia) in 2017. This thematic issue of BMC Evolutionary Biology issue cover the papers presented at Young Scientists School "Systems Biology and Bioinformatics - 2017" (SBB-2017) and Belyaev memorial conference "Belyaev Readings 2017" (BR-2017). Previously published special issues of BMC Evolutionary Biology and BMC Genomics covered the proceeding of BGRSISB-2016 conference and SBB2015 School in Novosibirsk [1-4] as well as BGRS\SB-2014 event (https://bmcgenomics.biomedcentral.com/articles/ supplements/volume-15-supplement-12).

In it important to note that Year 2017 marks the 100th anniversary since birth of Full Member of the USSR Academy of Sciences, Professor Dmitry K. Belyaev (1917-1985), an outstanding scientist, evolutionist and geneticist. In view of this memorable date, the Institute of Cytology and Genetics of the Siberian Branch of the Russian Academy of Sciences (ICG SB RAS) held international Belyaev Conference on Genetics and Evolution (Novosibirsk, August 7-10, 2017 - http://conf.bionet.ns c.ru/belyaev100/en).

Back in 1950s, Russian (Soviet) geneticist Dmitry Konstantinovich Belyayev embarked on a journey to turn aggressive, wily silver fox into a domestic animal as friendly and tail-wagging as a dog. Belyaev was inspired by Darwin's early observations on similarity of morphologic and physiologic changes observed in various domestic animals. Hence, he hypothesized that domestication is, in fact, a selection for disposition toward humans and, therefore, it should involve the changes in

\footnotetext{
* Correspondence: orlov@bionet.nsc.ru

${ }^{1}$ Institute of Cytology and Genetics SB RAS, Novosibirsk, Russia

${ }^{2}$ Novosibirsk State University, Novosibirsk, Russia

Full list of author information is available at the end of the article
}

regulatory genes governing the behavior, the stress and the metabolism of sex hormones. As a result, a unique, world-famous tame fox population was generated. Belyaev demonstrated that the selection for human-friendly demeanor disrupts physiological and morphological systems of silver fox, thus, shifting the phenotype to that similar to the dogs and other now-tamed animals. With that, Belyaev opened up a totally new chapter in the theory of morphogenetic processes that explores interactions between two main factors in evolution: variability and selection. The results of a breathtaking experiment with thousands of animals led Belyaev to postulate a very special form of directional, destabilizing selection taking place in domestication. It destabilizes regulatory systems underlying ontogenesis and, as a consequence, sharply increases the rates at which new phenotypic forms emerge.

To highlight the significance of fox domestication experiments performed at the Institute of Cytology and Genetics SB RAS in Novosibirsk, the unique bronze monument to Academician D. K. Belyaev was built by collective efforts near the Institute, where he served as a Founding Director (http://icg.nsc.ru/belyaev100/en/ monument/). The tamed fox gives the Professor a paw and wags the tail (Fig. 1).

In 2017, "Vavilov Journal of Selection and Breeding" published a series of memoirs publications about Prof. Belyaev (http://vavilov.elpub.ru/jour/issue/view/32/show Toc). The article by Prof. V. K. Shumny [5] tells the history of Belyaev's life, while other publications discuss importance of Belyaev's work on the theory of evolution and domestication $[6,7]$.

Current issue of BMC Evolutionary Biology presents works describing evolutionary insights derived from observations and experiments with a range of lifeforms as large as the whales and as small as the microbes, uncovering novel adaptations.

Alexey A. Moskalev and co-authors [8] consider the problems of aging and longevity through the prism of 


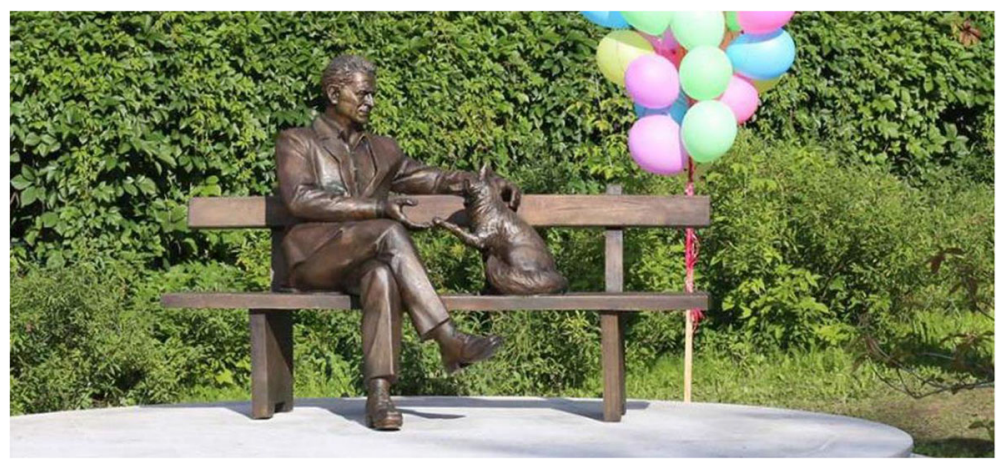

Fig. 1 Photo: The opening of the monument to D.K. Belyaev and tame fox. August 2017, Novosibirsk

marine biology. In their study, they assembled genome and transcriptome of a grey whale, which is often described as a "living fossil", adapted to extreme marine conditions. This work puts a cornerstone for further studies of whale evolution and longevity.

The work of Nataly E. Gruntenko and colleagues [9] consider the response to parasite-induced stress in a classical model of fruit fly. This team showed that the strains of Wolbachia differ in their respective influence towards dopamine metabolism of Drosophila and their survival under heat stress conditions.

Nadezhda L. Bolsheva and co-authors [10] presented their work in the area of plant evolution. After analysis of ribosomal RNA genes in various species of the blue-flowered flaxes (genus Linum), this research team made several adjustments to the phylogeny of these plant species, while also showing both intraand interspecific divergence of their rRNA-encoding genes.

Alexey S. Rozanov et al. [11] describe biodiversity of microbial organisms living in extreme natural conditions within the microbial mats of alkaline hot spring Garga within the river Barguzin of the Baikal rift zone. They showed a high abundance of novel species of Archaea and the domains of heterotrophic organisms. Studied microbial mats had evolved in early stages of biosphere formation.

Elena V. Ignatieva [12] and colleagues discuss problems of human response to tick-borne encephalitis virus infection and reconstruct the networks of human genes involved in such response. In their article evolutionary problems of human adaptation to parasites and infections are discussed.

Follow-on series of related works in the areas of classical and medical genomics, genetics, and plant biology discussed at "Belyaev conference - 2017" and other related meetings in Novosibirsk and Moscow will be published in Special Issues of BMC Genetics, BMC Genomics, BMC Medical Genomics, BMC Plant Biol and BMC Neuroscience.

\section{Acknowledgements}

The authors and the conference Committee acknowledge work of the Conference Chairman Academician Prof. Nikolay A. Kolchanov and support by Academician Vladimir K. Shumny, Prof. Ludmila N. Trut as well as the local committee members.

The guest editors of the special issue are grateful to the reviewers who helped in the articles editing and issue preparation: Tatiana Tatarinova, Meisheng Yi, Andrey Ptitsyn, Ivan Dubovskiy, Alexander Mikheyev, Mikhail Shaposhinkov, Ming Chen, Christopher Cullis, Lothar Krienitz, Kian Mau Goh, Ralf Hofestaedt, Mária Kazimírová, Ivan Kulakovsky, Karen Mansfield, Julio Fernandez.

Continuing studies of wild and domesticated foxes $(\mathrm{YH})$ were supported by RSF (grant no. 16-14-10216): "Integrated Analysis of Gene Expression in the Brain of the Tame Foxes: A Study on a Unique Selection Model of Domestication". Biodiversity researches $(\mathrm{YO})$ were supported by the by Ministry of Education and Science of the Russian Federation grant \#14.W03.31.0015.

\section{About this supplement}

This article has been published as part of BMC Evolutionary Biology Volume 17 Supplement 2, 2017: Selected articles from Belyaev Conference 2017: evolutionary biology. The full contents of the supplement are available online at https://bmcevolbiol.biomedcentral.com/articles/supplements/ volume-17-supplement-2.

\section{Authors' contributions}

$A B$ and $Y H$ selected the works presented at the conference for publication. $A B, Y H$ and $Y O$ are Program Committee members and guest editors of this journal issue. YO wrote the manuscript. All authors read and approved the final manuscript.

\section{Competing interests}

The authors declare that they have no competing interests.

\section{Publisher's Note}

Springer Nature remains neutral with regard to jurisdictional claims in published maps and institutional affiliations.

\section{Author details}

${ }^{1}$ Institute of Cytology and Genetics SB RAS, Novosibirsk, Russia. ${ }^{2}$ Novosibirsk State University, Novosibirsk, Russia. ${ }^{3}$ George Mason University, Fairfax, USA. ${ }^{4}$ Research Centre of Medical Genetics, Moscow, Russia.

Published: 28 December 2017

\section{References}

1. Baranova AV, Orlov YL. The papers presented at 7th Young Scientists School "Systems Biology and Bioinformatics" (SBB'15): introductory note. BMC Genet. 2016:17(Suppl 1):20. doi:10.1186/s12863-015-0326-5.

2. Orlov YL, Hofestädt RM, Kolchanov NA. Introductory note for BGRSISB-2014 special issue. J Bioinform Comput Biol. 2015;13(1):1502001. doi:10.1142/ S0219720015020011. 
3. Orlov YL, Baranova AV, Hofestädt R, Kolchanov NA. Computational genomics at BGRSISB-2016: introductory note. BMC Genomics. 2016; 17(Suppl 14):996. doi:10.1186/s12864-016-3350-6.

4. Baranova AV, Orlov YL. Evolutionary biology at BGRSISB-2016. BMC Evol Biol. 2017;17(Suppl 1):21. doi:10.1186/s12862-016-0869-8.

5. Shumny VK. To the centenary of the birth of outstanding evolutionist Dmitri Konstantinovich Belyaev. Vavilovskii Zhurnal Genetiki i Selektsii = Vavilov. J Genet Breed. 2017;21 (4):387-91. doi:10.18699/NJ17.256 (In Russian).

6. Trut LN, Kharlamova AV, Vladimirova AV, Herbeck YE. On selection of foxes for enhanced aggressiveness and its correlated implications. Vavilovskii Zhurnal Genetiki i Selektsii = Vavilov. J Genet Breed. 2017;21(4):392-401. doi: 10.18699/NJ17.257 (In Russian).

7. Wilkins AS. Revisiting two hypotheses on the "domestication syndrome" in light of genomic data. Vavilovskii Zhurnal Genetiki i Selektsii = Vavilov. J Genet Breed. 2017:21(4):435-42. doi:10.18699/NJ17.262.

8. Moskalev AA, Kudryavtseva AV, Graphodatsky AS, Beklemisheva VR, Serdyukova NA, Krutovsky KV, Sharov W, Kulakovsky IV, Lando AS, Kasianov AS, Kuzmin DA, Putintseva YA, Feranchuk SI, Shaposhnikov MV, Fraifeld VE, Toren D, Snezhkina AV, Sitnik W. De novo assembling and primary analysis of genome and transcriptome of gray whale Eschrichtius robustus. BMC Evol Biol. 2017;17(Suppl 2):S2 (This issue).

9. Gruntenko NE, llinsky YY, Adonyeva NV, Burdina EV, Bykov RA, Menshanov PN, Rauschenbach IY. Various Wolbachia genotypes differently influence host Drosophila dopamine metabolism and survival under heat stress conditions. BMC Evol Biol. 17(Suppl 2):S3 (This issue).

10. Bolsheva NL, Melnikova NV, Kirov IV, Speranskaya AS, Krinitsina AA, Dmitriev AA, Belenikin MS, Krasnov GS, Lakunina VA, Snezhkina AV, Rozhmina TA, Samatadze TE, Yurkevich OY, Zoshchuk SA, Amosova AV, Kudryavtseva AV, Muravenko OV. Evolution of blue-flowered species of genus Linum based on high-throughput sequencing of ribosomal RNA genes. BMC Evol Biol. 17(Suppl 2):S4 (This issue).

11. Rozanov AS, Bryanskaya AV, Ivanisenko TV, Malup TK, Peltek SE. Biodiversity of the microbial mat of the Garga hot spring. BMC Evol Biol. 17(Suppl 2):S5 (This issue).

12. Ignatieva $\mathrm{EV}$, Igoshin $\mathrm{AV}$, Yudin NS. A database of human genes and a gene network involved in response to tick-borne encephalitis virus infection. BMC Evol Biol. 17(Suppl 2):S6 (This issue).

\section{Submit your next manuscript to BioMed Central and we will help you at every step:}

- We accept pre-submission inquiries

- Our selector tool helps you to find the most relevant journal

- We provide round the clock customer support

- Convenient online submission

- Thorough peer review

- Inclusion in PubMed and all major indexing services

- Maximum visibility for your research

Submit your manuscript at www.biomedcentral.com/submit

) Biomed Central 